THOMAS P. JOHANSEN

\section{Astetisk tænkning}

Dorthe Jorgensen: Aglaias Dans - På vej mod en astetisk tankning, Aarbus Universitetsforlag, 2008, 392 sider, 298,- kr.

Idéhistoriker og dr.phil. Dorthe Jørgensen har samlet 34 tekster til en tankevækkende bog om skønhed, sandhed og tænkning - men også om dannelse, intellektualisme og idéhistorie. Teksterne, hvoraf nogle har været udgivet før, andre ikke, er opdelt i to dele: "Sandhed" og "Tænkning". Alle har de et fælles underliggende tema $i$ et forsvar for den besindige refleksion. Teksterne tæller både kronikker, videnskabelige artikler, interviews, disputatsforsvarstale og sokratiske dialoger ("Tankens fest. I anledning af Martin Heideggers fortælling om Grækenland" som uden tvivl tager prisen som den særeste og mest iscenesatte tekst i samlingen). Bogen fremstår derved lige så fragmenteret og disharmonisk som det romantiske kunstbegreb, som Jørgensen er betydeligt inspireret af. Men det lykkedes ikke desto mindre at fremmane den enhed ved mangfoldighed som denne værktype kræver. Om det er skønheden som viser sig for beskueren, og hvad dette i så fald må betyde, står nok til diskussion.

Med den filosofiske æstetik som førstefilosofi giver Jørgensen sit bud på, hvordan vi nærmer os en tænkning, hvis udbytte er mening og visdom. Det vil sige, til forskel fra viden, som det for tiden så højt besungne videnssamfund konsumerer. En sådan tænkning må være fænomenologisk og hermeneutisk. Dette betyder for Jørgensen en tænkning som anerkender en sandhedsværdi i erfaringen af merbetydning - også kaldet skønhedserfaring, guddommelighedserfaring eller metafysisk erfaring - som, fra tid til anden, spontant fremtræder for os i mødet med det skønne; f.eks. i kunsten, ved mellemmenneskeligt samvær eller i naturen. Den filosofiske æstetik er en erkendelsesteori. Den sandhed, vi her erfarer, er, ifølge Jørgensen, ikke en sandhed om verden, men om vor egen plads i verden. En sandhed, hvis vidensform er nært beslægtet med den aristoteliske phronesis, der knytter sig til værensformen praxis; handlingslivet. Det er samtidig en tænkning, som giver indsigt $\mathrm{i}$ menneskets historicitet. Netop derfor er det vigtigt, at der er tale om 
erfaring og ikke oplevelse. Oplevelsen sker i nuet, men i det næste nu er den væk. Erfaringen fremtvinger derimod refleksion, en dvælen-ved, som forbinder nuet med hvorfra'et og hvorhen'et, og som den enkelte tager med sig i sin praxis. Der er med andre ord tale om andet og mere end en tilfredsstillelse af sanserne. Det er en helt særlig sensibilitet, som gør sig gældende, en æstetisk rationalitet eller fornuft.

I den første del, "Sandhed", får vi på forskellig vis præsenteret denne erkendelsesteori. Dels som idéhistoriske redegørelser af skønhedens og æstetikkens metamorfoser. Dels som udlægninger af Jørgensens egne skønhedserfaringer og filosofisk æstetiske læsninger af værker. Det er især her Jørgensen udfolder sig sprogligt. Det er dog påfaldende at disse læsninger overvejende er centreret omkring kunstværket, skønt vi igen og igen får at vide, at kunsten netop ikke har monopol på skønheden og derved sandheden.

Men ikke alt er bare skønt. Der ligger tilsyneladende en stor og faretruende sky over os. Den instrumentelle fornuft, som ifølge Jørgensen er dominerende i tidsånden, truer med at kvæle dannelsen. Dette gør sig bl.a. (og ikke mindst) gxldende $\mathrm{i}$ forbindelse med politiske beslutninger vedrørende uddannelse, universitet og forskning.
Skønt Jørgensen i tekst efter tekst forsøger at bidrage positivt til, hvad vi kan kalde fornuftens selvrefleksion, brister den æstetiske boble dog indimellem. Den ellers solide stil og skudsikre opstilling af en æstetisk tænkning overmandes til tider af en rationalitetskritik, som fremstår mere følelsesladet end fornuftbetonet. Tydeligst kommer dette til udtryk i artiklen "Den intellektuelle livsform”, hvor Jørgensen maler et noget romantisk billede af landmandslivet, som her bliver anset som nært idealet for den selvstændige livsform. Den livsform som danner forbillede for Jørgensens nye intellektuelle livsform, som nærmere er en værensform. Jørgensens problem er bare at selv landbruget, menneskets ældste og mest basale form for arbejde, nu er blevet inficeret af den instrumentelle rationalitet. Umiddelbart fremstår dette eksempel noget utidsvarende. Den idé om fremmedgørelse og mistanken om en art falsk bevidsthed (lønmodtagerne bliver, ifølge Jørgensen, bildt ind at de lever en karrierelivsform, hvori de arbejder for deres egen skyld, men i virkeligheden udøver de kun markedets ønske om mer-produktion), som her er på spil, kender vi fra en lang modernitets- og civilisationskritisk tradition, som vi kan føre tilbage til f.eks. Adorno og Horkheimer - ja måske helt tilbage 
til Rousseau. Jørgensens bidrag til denne tradition er, at hun her, ved hjælp af Thomas Højrups livsformsanalyser, forsøger at trække kritikken ud af den klassiske klassetænkning og bringe den i spil på en mere aktuel måde. Det kan måske nok betvivles, om dette er nok til at flytte noget. Fokus på arbejdet - poesis - er klart nok og indlysende relevant for tilnærmelsen af en praxis-poesis væremåde. Men det kan undre, at det overhovedet er interessant for Jørgensen at operere med kategorier på denne måde, da dette må betyde at indordne det partikulære under det almene, og ikke, som hensigten med projektet ellers er, at betænke det almene ved det partikulære.

Professor i Idéhistorie HansJørgen Schanz diskvalificerede for snart 20 år siden kunsten og xstetikken som privilegeret ståsted for en rationalitetskritik. Jørgensen vil sandsynligvis påpege hertil, at Schanz ikke har blik for den, “æstetikologiske differens” og derfor tænker på kunstfilosofi og ikke (filosofisk) æstetik. Det vil sige, at Schanz for så vidt kan have ret $\mathrm{i}$, at hvis man lukker sig inde i kunstens egen verden og logik, afskærer man sig fra den fornufts sfære, som man ønsker at kritisere. Derved bliver man dogmatisk. Men forstås xstetikken derimod som filosofisk æstetik, altså som den erkendelsesteori om det sande ved det skønne, som ifølge Jørgensen var meningen med xstetikbegrebet, da det blev dannet for næsten 200 år siden, kan den bruges som korrektiv til den logiskrationelle fornuft. Og det er det, der ifølge Jørgensen er behov for. I denne forstand besidder æstetikken en særlig mulighed for at fremføre rationalitetskritik.

Anden del af bogen, "Tænkning", handler om idéhistorie, dannelse og de intellektuelles rolle og ansvar. I en tid hvor det postmoderne ikke blot har slået skønheden ihjel, men også (eller måske netop derved) sandheden, efterlyser Jørgensen ægte intellektuelle som kan tænke kritisk, og som vil dele disse tanker. Den antimetafysiske strømning, som har vundet frem i de sidste tiår, mener Jørgensen ligefrem udhuler moralen. På universiteterne viser dette sig ved et stigende antal karriereakademikere. Disse udtaler sig politisk korrekt; "objektivt". De siger derfor ikke mere end, hvad deres egne fortsatte ansættelser kan holde til. Man er blevet bange for at tænke kritisk. En æstetisk tænkning spiller her en central rolle for dannelsen. Både som vagthund $\mathrm{og}$ mere direkte i skolen og på gymnasiet. Internettets allestedsnærvær har reelt gjort indlæring af hårde facts overflødig. Hvornår Christian IV blev kronet eller hvem der underskrev Danmarks første grund- 
lov kan vi slå op. Det er i højere grad historiebevidsthed, som vi har brug for indsigt i, og det er her idéhistorikeren skal på banen.

Jørgensen er tydeligvis klar over, at hvis man vil kritisere uden at forfalde til brok, må man også komme med et alternativ, og her tilbyder hun selv skønheden. Det vanskelige ved Jørgensens projekt er bare, at hun samtidig med at overbevise også skal omskole til en helt anden måde at tænke æstetik på, end den som i de sidste mindst 100 år har gjort sig gældende.

Aglaias Dans henvender sig både til faste tilhængere af Jørgensen, som vil læse sig dybere ind $\mathrm{i}$ æstetikken som kritisk tænkning, og til læseren, som ønsker korte introduktioner til den filosofiske æstetik. Men den tjener også i høj grad, og måske vigtigst, som en opfordring til efterfølgelse. Uanset om man anser æstetikken som en gang lommefilosofisk føleri, eller om man anerkender dens fordring på sandhed, formår Jørgensen, om ikke andet, at reflektere over, hvad idéhistorien er og kan være, og hvad den kan bidrage med over for den bredere befolkning. Visdom er ikke forbeholdt de få ophøjede i elfenbenstårnet, men bør være tilgængelig for alle. Jørgensen har en idé om, hvordan denne opgave skal angribes. Har du?
MARTIN BLOK JOHANSEN

\section{Distanceret involverethed eller involveret distance?}

Mogens Pabuus: Distance og involverethed - et tema i eksistenstankning og elesistensdigtning, Aalborg Universitetsforlag, 2008, 160 sider, 199,- kr.

Året efter at han havde udgivet sin disputats om Søren Kierkegaard, Kierkegaard. Konstruktion des Ästhetischen, skriver Theodor Adorno til sin ven, den østrigske komponist Ernst Krenek, at professor Gomperz fra universitetet i Wien mente, at i Adornos Kierkegaard-bog "var det egentlig kun citaterne, der var interessante". Noget lignende kunne man sige om Mogens $\mathrm{Pa}$ huus' bog om eksistenstænkning og eksistensdigtning, Distance og involverethed. Hvis man var fræk og kæk nok. Det er jeg ikke, så jeg nøjes med at sige, at citaterne i Pahuus' bog er meget interessante. Hvis de bliver opfattet som det mest interessante, er det ikke Pahuus' skyld. Eller, så er det netop Pahuus'skyld. Pahuus er nemlig eminent, når det handler om at opspore og fremdrage de mest elegante, fornøjelige og mesterlige citater fra de værker, han bruger. Fx når Milan Kundera i Langsombeden kalder forbindelsen mellem langsomhed og nydelse 